\title{
Community Diagnosis on Health Seeking Behavior and Social Problems in Bhaktapur and Kavrepalanchok Districts of central Nepal
}

\author{
Pratibha Manandhar, Naresh Manandhar, Ram Krishna Chandyo, Sunil Kumar Joshi \\ Department of Community Medicine, Kathmandu Medical College, Duwakot, Bhaktapur
}

\section{Correspondence \\ Dr. Pratibha Manandhar, \\ Lecturer, \\ Department of Community \\ Medicine, \\ Kathmandu Medical College, \\ Duwakot, Bhaktapur}

\section{Email:}

pratibhamanandhar@gmail.com

DOI: http://dx.doi.org/10.3126/ jemsn.v13i3.17581

Orcid ID: orcid.org/0000-00032071-1347

Article received: June $24^{\text {th }} 2017$ Article accepted: Sept $26^{\text {th }} 2017$

\begin{abstract}
Background \& Objectives: The main objectives of this study were to assess the health status, health seeking behaviors and social problems of Bhaktapur and Kavrepalanchok districts and also to learn the research skills and establish relation with community for students. Materials \& Methods: This was a cross sectional study conducted by students of second year MBBS for educational purposes of community diagnosis program (CDP) in one week period in nine VDC (village development committee) of Bhaktapur district along with one VDC and one municipality of Kavrepalanchok district. Household were selected based on convenient sampling method for the feasibility of students. Ethical clearance for the study was taken from Institutional Review Committee (IRC) of Kathmandu Medical College. Results: A total of 211 and 105 households from Bhaktapur and Kavrepalanchok districts respectively were included in this study. In Bhaktapur district, a slight female predominance $549(50.42 \%)$ was observed, whereas in Kavrepalanchok district male predominated marginally $270(51.1 \%)$. In Bhaktapur district, $35(47.9 \%)$ were addicted to alcohol and smoking behaviors, whereas in Kavrepalanchok district it was 12 (29.3\%). In Bhaktapur and Kavrepalanchok districts, $102(48.3 \%)$ and $50(47.61 \%)$ households respectively consulted in hospital when became sick. The most prevalent health problem was cardiovascular diseases in both the districts i,e $39(39 \%)$ in Bhaktapur and $14(37.8 \%)$ in Kavrepalanchok district respectively. Conclusion: Community diagnosis program assisted students to identify problems in the community, to raise the health awareness, practicing research skills and establishing relations with the community. The community also benefitted by getting knowledge on improving the health status and social aspects from the students during their door to door visit.

Key words: Community diagnosis program (CDP); Health seeking behavior; Social problems
\end{abstract}

Citation: Manandhar P, Manandhar N, Chandyo RK, Joshi SK. Community Diagnosis on Health Seeking Behavior and Social Problems in Bhaktapur and Kavrepalanchok Districts of central Nepal. JCMS Nepal. 2017;13(3):335-9.

\section{INTRODUCTION}

Community diagnosis refers to the identification and quantification of health problems in a community in terms of mortality and morbidity rates and ratios, identification of their correlates for the purpose of defining those individuals or groups at risk or those in need of health care. ${ }^{1}$ Community diagnosis program (CDP) is a community-oriented educational program for medical students which includes the teaching learning activities within the community for students and gives idea to policy makers for planning and improving the health care delivery system.

Nepal Government's new health policy, National Health Education, Information and Communication Centre (NHEICC) is supporting the health 
awareness on communicable and non $\square$ communicable Diseases to improve the health status of the population and strengthen action against the social problems. ${ }^{2}$ Smoking and the use of other tobacco products kill 15,000 people in Nepal each year. ${ }^{3}$ Smoking prevalence varies among schools (2\% to $49 \%)$ and districts $(7 \%$ to $29 \%)^{4}$ Therefore, preventing tobacco use and smoking initiation in adolescents is a public health concern that aims to reduce many chronic degenerative diseases (e.g. cardiovascular diseases, chronic respiratory diseases, and cancer). ${ }^{5}$ The main objectives of this study was to assess the health status, health seeking behaviors and to identify social problems of Bhaktapur and Kavrepalanchok districts.

\section{MATERIALS AND METHODS}

This is a cross sectional study conducted by second year MBBS students for educational purposes of community diagnosis program (CDP) based on curriculum of Kathmandu Medical College under supervision of faculties of Community Medicine Department including the author. The data collection period was of one week (24th to 29th April 2016) in nine VDC (village development committee) of Bhaktapur district (i.e. Balkot, Dekocha, Jagati, Suryabinayak, Balkumari, Bageshwori, Dadhikot, Gundu and Changunarayan) along with one VDC (i.e Nala) and one municipality (i,e Panauti) of Kavrepalanchok district. One week orientation and preparation were provided to the students before the study period. Additionally, one week timeline was allocated to analysis and presentation of reports. Household were selected based on convenient sampling method for the feasibility of students. One hundred and fifty students were divided into six groups (25 in each group). Each group was supervised by a faculty member and all the students were given orientation about the Sub Health Post and Health Post of that particular place by female community health volunteer (FCHV). The students were further assisted by FCHV of each ward to collect data. Students collected data from the households of different wards of VDCs as described above. The data collection tools used were pre-tested questionnaires, weighing machines, measuring tapes, stethoscopes and sphygmomanometers. Verbal consent was taken from each participant. The interview was conducted with one available family member of the household representing their family. The topics covered in household survey

questionnaire were demographic profile, educational status, occupation, social problems, nutritional status, health seeking behavior and health status. Ethical clearance for the study was taken from Institutional Review Committee (IRC) of Kathmandu Medical College. Data were entered in excel database programme and later transferred into SPSS (Statistical package of social science) 18 version. Analyses were done in percentage and frequency tabulation.

\section{RESULTS}

A total of 211 households in Bhaktapur and 105 households in Kavrepalanchok districts were included in this study. In Bhaktapur district, 540 $(49.58 \%)$ were males and 549(50.42\%) were females whereas in Kavrepalanchok district 270 (51.1\%) were males and 259 (49.9\%) were females. There were Newar predominance in both the communities, $128(60.6 \%)$ in Bhaktapur and 47

Table 1: Socio-Demographic profile

\begin{tabular}{|c|c|c|c|c|}
\hline \multirow[t]{2}{*}{ Variables } & \multicolumn{2}{|c|}{ Bhaktapur } & \multicolumn{2}{|c|}{$\begin{array}{l}\text { Kavrepalan- } \\
\text { chok }\end{array}$} \\
\hline & $\begin{array}{l}\text { No. of } \\
\text { House- } \\
\text { holds }\end{array}$ & $(\%)$ & $\begin{array}{l}\text { No. of } \\
\text { House- } \\
\text { holds }\end{array}$ & $(\%)$ \\
\hline \multicolumn{5}{|l|}{ Sex } \\
\hline Male & 540 & (49.58) & 270 & (51.1) \\
\hline Female & 549 & $(50.42)$ & 259 & (48.9) \\
\hline Total & 1089 & (100) & 529 & (100) \\
\hline \multicolumn{5}{|l|}{ Caste } \\
\hline Newar & 128 & $(60.6)$ & 47 & (44.8) \\
\hline Chhetri & 37 & $(17.5)$ & 34 & (32.4) \\
\hline Brahmin & 21 & (10) & 18 & (17.1) \\
\hline Tamang & 10 & (4.8) & 1 & $(0.9)$ \\
\hline others & 15 & (7.1) & 5 & $(4.8)$ \\
\hline \multicolumn{5}{|l|}{$\begin{array}{l}\text { Family } \\
\text { types }\end{array}$} \\
\hline Nuclear & 109 & (51.6) & 57 & (54.3) \\
\hline Joint & 58 & $(27.5)$ & 22 & $(21)$ \\
\hline Extended & 44 & (20.9) & 26 & (24.7) \\
\hline \multicolumn{5}{|l|}{ Religion } \\
\hline Hindu & 199 & (94.4) & 102 & (97.1) \\
\hline Buddhist & 11 & $(5.1)$ & 3 & (2.9) \\
\hline Christian & 1 & $(0.5)$ & 0 & $(0)$ \\
\hline Total & 211 & (100) & 105 & (100) \\
\hline
\end{tabular}


Table: 2 Educational Status

\begin{tabular}{lcccc} 
Education & \multicolumn{2}{c}{ Bhaktapur } & \multicolumn{2}{c}{$\begin{array}{c}\text { Kavrepalan- } \\
\text { chok }\end{array}$} \\
& No. & \% & \multicolumn{1}{c}{ No. } & \% \\
\hline Illiterate & 203 & 20.0 & 70 & 14.0 \\
\hline Literate & 97 & 9.5 & 57 & 11.3 \\
\hline Primary & 195 & 20.0 & 85 & 17.0 \\
\hline Secondary & 211 & 20.0 & 114 & 22.7 \\
\hline $\begin{array}{l}\text { Higher sec- } \\
\text { ondary }\end{array}$ & 165 & 16.2 & 100 & 20.0 \\
\hline $\begin{array}{l}\text { Bachelor } \\
\text { Master }\end{array}$ & 125 & 12.3 & 59 & 11.7 \\
\hline $\begin{array}{l}\text { Total } \\
\text { (family } \\
\text { members) }\end{array}$ & $\mathbf{1 0 1 7}$ & 21.0 & 17 & 3.3 \\
\hline
\end{tabular}

- Under 5years of age were not used for analysis of education status

Table 3: Addiction habits

\begin{tabular}{|c|c|c|c|c|}
\hline \multirow{2}{*}{$\underset{\text { Any Addic- }}{\text { Anon }}$} & \multicolumn{2}{|c|}{ Bhaktapur } & \multicolumn{2}{|c|}{ Kavrepalanchok } \\
\hline & No. & $\%$ & No. & $(\%)$ \\
\hline Yes & 73 & 34.6 & 41 & 39.0 \\
\hline No & 138 & 65.4 & 64 & 61.0 \\
\hline Total & 211 & 100 & 105 & 100 \\
\hline \multicolumn{5}{|c|}{ Type of addiction } \\
\hline Smoking* & 27 & 37.0 & 25 & 61.0 \\
\hline Alcohol* & 10 & 13.7 & 4 & 9.7 \\
\hline $\begin{array}{l}\text { Both Alco- } \\
\text { hol and } \\
\text { Smoking* }\end{array}$ & 35 & 47.9 & 12 & 29.3 \\
\hline Drugs * & 1 & 1.4 & 0 & 0.0 \\
\hline Total & 73 & 100 & 41 & 100 \\
\hline
\end{tabular}

\section{*Multiple responses}

(44.8\%) in Kavrepalanchok district respectively. Similarly, nuclear family were predominant 109 $(51.6 \%)$ in Bhaktapur and $57(54.3 \%)$ in Kavrepalanchok district respectively. Most of them were Hindu by religion in both districts 199 (94.4\%) in Bhaktapur and $102(97.1 \%)$ in Kavrepalanchok shown in Table 1.

While analyzing the education status exempting children below six years, secondary level of education was found among residents of Bhaktapur $211(20 \%)$ and Kavrepalanchok district 114
(22.7\%). By contrast,203 (20\%) in Bhaktapur and 70 (14\%) in Kavrepalanchok district were illiterate, where under 5 years of age were not included for analysis of education status. In relation to occupation, the percentages of housework were higher $165(23.5 \%)$ in Bhaktapur, while in Kavrepalanchok district the number of college employee were higher 103 (36.4\%) as depicted in Table 2, where under 18 years of age were excluded for the analysis.

Of the total households, 73 (34.6\%) of Bhaktapur and $41(39 \%)$ of Kavrepalanchok districts found some form of addictions habits in the family. of which in Bhaktapur district, 35 (47.9\%) households have both alcohol and smoking addiction whereas in Kavrepalanchok district it was 12 (29.3\%) illustrated in Table 3. As shown in Fig. 1 the commonest occupation was housework $23.5 \%$ and school employee $36.4 \%$ in kavrepalnchok district In both Bhaktapur and Kavrepalanchok districts, $102(48.3 \%)$ and 50 (47.61\%) households respectively consulted in hospital when became sick. (Fig. 2) The most prevalent health problem

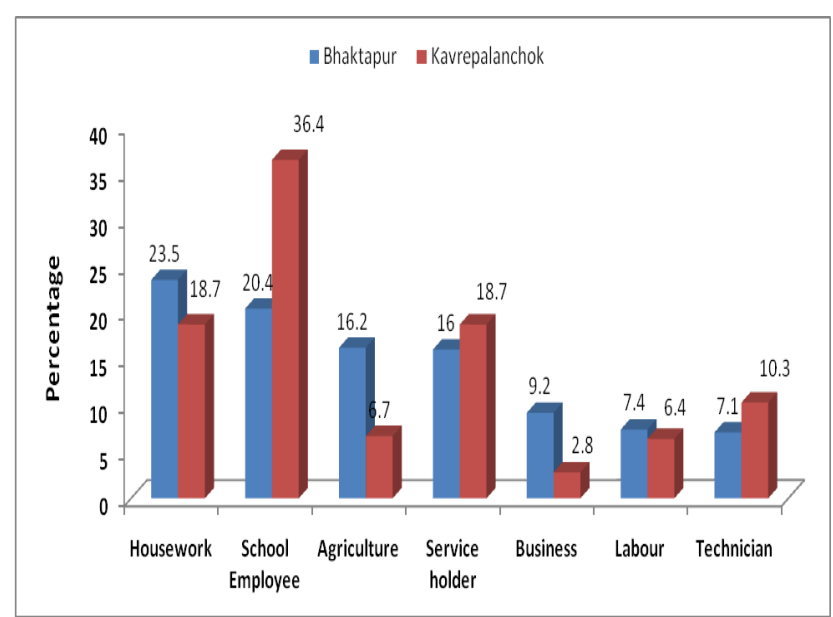

Figure 1: Occupational status. ${ }^{\#}$ Less than 18 years were not included in this analysis

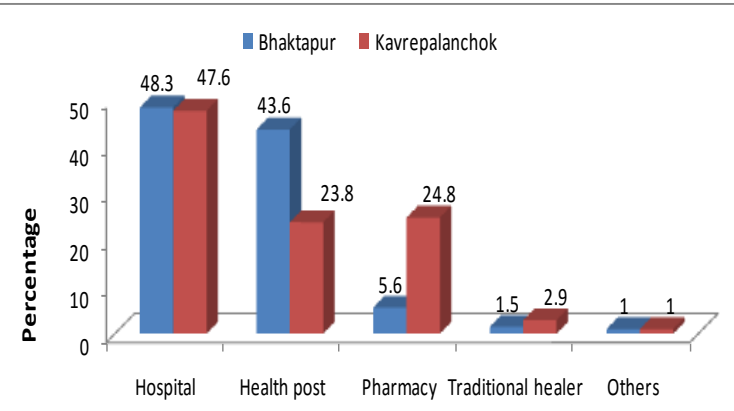

Figure 2: Consultation by clients at Health Facility when became sick 
Table 4: Types of disease prevalence

\begin{tabular}{|c|c|c|c|c|c|c|}
\hline \multirow{2}{*}{$\begin{array}{l}\text { Disease } \\
\text { concerned }\end{array}$} & \multirow{2}{*}{ S.N } & \multirow{2}{*}{ Name of Diseases } & \multicolumn{2}{|c|}{ Bhaktapur } & \multicolumn{2}{|c|}{ Kavrepalanchok } \\
\hline & & & No & $\%$ & No & $\%$ \\
\hline \multirow{4}{*}{$\begin{array}{l}\text { Cardio } \\
\text { Vascular Sys- } \\
\text { tem }\end{array}$} & 1 & Hypertension & 32 & (32) & 9 & $(24.3)$ \\
\hline & 2 & Cardiac diseases & 5 & $(5)$ & 2 & (5.4) \\
\hline & 3 & Hypotension & 2 & (2) & 3 & $(8.1)$ \\
\hline & & Total & 39 & (39) & 14 & (37.8) \\
\hline \multirow{5}{*}{$\begin{array}{l}\text { Respiratory } \\
\text { Diseases }\end{array}$} & 1 & Bronchial Asthma & 19 & (19) & 3 & $(8.1)$ \\
\hline & 2 & Lung Cancer & - & - & 1 & (2.7) \\
\hline & 3 & COPD & 2 & (2) & 1 & (2.7) \\
\hline & 4 & Pneumonia & - & - & 1 & (2.7) \\
\hline & & Total & 21 & (21) & 6 & (16.2) \\
\hline \multirow{3}{*}{$\begin{array}{l}\text { Metabolic Dis- } \\
\text { eases }\end{array}$} & 1 & Diabetes & 13 & (13) & 3 & $(8.1)$ \\
\hline & 2 & Hypothyroidism & 9 & (9) & 1 & (2.7) \\
\hline & & Total & 22 & (22) & 4 & (10.8) \\
\hline \multirow{2}{*}{$\begin{array}{l}\text { Gastro } \\
\text { Intestinal } \\
\text { System }\end{array}$} & 1 & Acid Peptic Disease Gastritis & 4 & (4) & 2 & $(5.4)$ \\
\hline & & Total & 4 & (4) & 2 & (5.4) \\
\hline \multirow{2}{*}{$\begin{array}{l}\text { Opthalmic } \\
\text { Diseases }\end{array}$} & 1 & Conjunctivitis & 4 & (4) & 1 & $(2.7)$ \\
\hline & & Total & 4 & (4) & 1 & (2.7) \\
\hline \multirow{3}{*}{$\begin{array}{l}\text { Psychiatric } \\
\text { Diseases }\end{array}$} & 1 & Mentally retarded & - & - & 1 & $(2.7)$ \\
\hline & 2 & Depression & 2 & (2) & - & - \\
\hline & & Total & 2 & (2) & 1 & (2.7) \\
\hline \multirow{6}{*}{ Others } & 1 & Paralysis & - & - & 3 & $(8.1)$ \\
\hline & 2 & Arthritis & 7 & (7) & 5 & 13.6) \\
\hline & 3 & Anemia & - & - & 1 & (2.7) \\
\hline & 4 & Physically disabled & 1 & (1) & - & - \\
\hline & & Total & 8 & (8) & 9 & (24.4) \\
\hline & & Grand Total & 100 & (100) & 37 & $(\mathbf{1 0 0})$ \\
\hline
\end{tabular}

was cardiovascular diseases in both the districts i,e $39(39 \%)$ in Bhaktapur and $14(37.8 \%)$ in Kavrepalanchok district respectively depicted in table 4. The diseases of various systems eg. Cardiovascular, Respiratory, Gastrointestinal etc. were illustrated in detail in Table 4.

\section{DISCUSSION}

A study conducted by Shrestha $\mathrm{L}$ et $\mathrm{al}^{6}$ found that nuclear family is more common among the types of families in VDCs of Kathmandu district (Dahachowk 56.7\%, Bhimdhunga 54.2\%, Sangla $62 \%$ and Ramkot $61.8 \%$ ). This was also reflected in our study as nuclear family is the most common in both districts $(51.6 \%$ in Bhaktapur and $54.3 \%$ in Kavrepalanchok respectively).

The same study postulated as chest problem is the most prevalent among different VDCs of Kathmandu district (Dahachowk VDC 13.7\%, Bhimdhunga $14.2 \%$, Sangla $10.2 \%$, Ramkot $13.9 \%)^{6}$ Additionally, Vaidya $\mathrm{A}$ et $\mathrm{al}^{7}$ in Gundu VDC of Bhaktapur district observed Gastrointestinal diseases (28\%) as the most prevalent health condition.By contrast, our study demonstrated the Cardiovascular illness was most commonest in both districts (39\% in Bhaktapur and 
$37.8 \%$ in Kaverpalnchok district respectively) highlighting non-communicable disease (NCD) as the emerging common health issues in the society.

A study by Shrestha $\mathrm{L}$ et $\mathrm{al}^{6}$ in different VDCs of Kathmandu district postulated that maximum people visited Government health facility (Dahachowk 53\%, Bhimdhunga 78\%, Sangla 76\% and Ramkot $81 \%$ ) and Vaidya $\mathrm{A}$ et $\mathrm{al}^{7}$ found $68 \%$ people of Gundu VDC, Bhaktapur district visited hospital during their illness. In this study we have also demonstrated that $48.3 \%$ and $47.6 \%$ of the people of Bhaktapur and Kavrepalanchok districts respectively visited hospital for their illnesses. It showed that there is an increasing awareness in the given population to receive health care services from hospitals rather than approaching to traditional healers as in the olden days.

\section{CONCLUSIONS}

Community diagnose program helped students to identify problems of community, to raise the awareness of health, prevention and promotion strategies of health, practicing research skills and establishing relationship with community. Similarly, second year medical students are also benefitted from the necessary process of integrating clinical skills and a public health approaches. By visiting the community, students helped to provide health awareness and knowledge to the community regarding its health seeking behavior.

As non communicable diseases are on the rise in the world, the similar trend showed in this study. Thus, we have to focus more on preventing the noncommunicable diseases by providing health education, having physical exercises etc. Furthermore, both districts' family members sought medical consultations during their initial phase of illness in hospital. As such, it can be concluded that there are some awareness in the communities so as to visit modern health care facility rather than visiting the traditional healers.

\section{ACKNOWLEDGEMENTS}

The authors would like to thank all students of the previous second year MBBS (18th Batch), Kathmandu Medical College. We would also like to acknowledge the local administration, FCHV and communities of Nala and Panauti VDCs of Kavrepalanchok district and Balkot, Dekocha, Jagati, Suryabinayak, Balkumari, Bageshwori, Dadhikot, Gundu and Changunarayan VDCs of
Bhaktapur district. At last, but not the least, sincere hearty thanks to our faculty members Associate Professor Dr Abhinav Vaidya, Lecturer Dr Natalia Oli, supporting staff Mr. Sakul Basnet and Mr. Ram Sharan Neupane for their support and cooperation for this study.

Recommendation: This type of study can be replicated in a large scale to identify the different health and social behavioral problems representing whole districts.

Limitation of the study: This study does not represent the whole population of the Bhaktapur and Kavrepalanchok districts due to convenient sampling frame.

\section{Conflict of Interest : None declared}

\section{REFERENCES}

1. Hale C, Shrestha IB, Bhattacharya S. Community Diagnosis Manual. 1st edi. Kathmandu, Nepal: Health learning and materials centre, T.U. Institute of Medicine; 1996.

2. Ministry of health and population; Department of health services: Annual Report of Department of health services 2070-71, Kathmandu, Nepal: Ministry of health and population; 2071.

3. Aryal UR, Petzold M, Krettek. Perceived risks and benefits of cigarette smoking among Nepalese adolescents: a population-based cross-sectional study. BMC Public Health.2013 March; 187(13):1-9.

4. Kainulainen S, Kivelä S: I Will Never Smoke. Results of Anti Tobacco Teaching and Investigation in Schools in Nepal. 2012, Helsinki: Diaconia University of Applied Sciences.

5. U.S. Department of Health and Human Services: A report of the Surgeon General: preventing tobacco use among young people. 1994, Washington DC: Department of Health and Human Services.

6. Shrestha L, Pant SN, Rajbhandari SD, Malla SS, Zoowa SB. Community health profile of four VDCs of north -west part of Kathmandu. MJSBH. Jan-June 2013;12(1):32-36. https://doi.org/10.3126/mjsbh.v12i1.9090.

7. Vaidya A, Pradhan A, Joshi SK, Gopalakrishnan S, Dudani I. Acquaintance with the actuality: community diagnosis programme of Kathmandu Medical College at Gundu village, Bhaktapur, Nepal. KUMJ 2008;6(21):128-134. PMID: 18604130. 